Kemal Kozarić ${ }^{1}$

Emina Žunić Dželihodžić

\title{
RELATIONSHIP BETWEEN NON-PERFMORMING LOANS AND FINANCIAL STABILITY: EVIDENCE FROM BOSNIA AND HERZEGOVINA BANKING SECTOR
}

\begin{abstract}
Latest financial crisis resulted in non-performing loans growth what causes a lot of problems to financial stability of banking systems all around world. Aim of this paper was to examine the impulse response function of financial stability and non-performing loans in Bosnia and Herzegovina banking sector. For that purpose, non-performing loans were defined as dependent and financial stability was an independent variable. Vector autoregression analysis was employed in order to explore how the Bosnia and Herzegovina banking sector financial stability responds to the impulse of changes in non-performing loans. Data for financial stability and non-performing loans for the period 2000-2017 were used. Main goal of this research is analysis of financial stability response on changes in non-performing loans. Therefore, the purpose of this paper is modelling relations between non-performing loans and financial stability. The study showed that financial stability of Bosnia and Herzegovina banking sector negatively reacts to changes in non-performing loans. Regression model showed that increase in non-performing loans leads to deterioration in financial stability of the banking sector. Results indicate long-term and short-term connection between non-performing loans and financial stability. Furthermore, it was disclosed that changes in financial stability have been caused by changes in non-performing loans. These results indicate the importance of non-performing loans monitoring as one of the main sources of systematic risk which could threaten banking sector financial stability.
\end{abstract}

Keywords: non-performing loans, financial stability, impulse-response, banking, JEL : $G 00, G 2$

1 Associate Professor, School of Economics and Business, Sarajevo, e-mail: kemal.kozaric@efsa. unsa.ba

2 School of Economics and Business, Sarajevo, e-mail:zunic.emina@gmail.com 


\section{INTRODUCTION}

High level of non-performing loans in banking sector and rising tendency leads to increase of allocated assets for those loans, low profitability and potential deterioration of banking sector financial stability. Numerous research papers pointed out that increase in non-performing loans negatively effects economic growth by decrease in loanable funds. Therefore, banking sector financial stability is the greatest concern of regulatory authorities and other financial participants in Bosnia and Herzegovina. Financial literature as well as researches from other countries indicates the importance of non-performing loans in sense of banking sector financial stability. The maintenance of financial stability is of a huge importance, not just for Bosnia and Herzegovina, but also for other Balkan countries. Global financial crisis has opened a new chapter in observing the objectives of central banks. Last crisis has shown that the functioning of the economy and the financial system is less affected by inflation (if it does not exceed to the hyperinflation) then financial instability. In inflationary conditions real and financial system can operate with fewer or greater difficulties, however, in terms of financial instability there is a complete "paralysis" of real and financial flows. Central bank of Bosnia and Herzegovina under the financial stability means a condition in which financial system is capable to absorb shocks without significant disruptions in its temporary and future functioning, without negative effects on entire economy. The primary goal of Central bank of Bosnia and Herzegovina is financial stability maintenance. The task of the Central Bank of Bosnia and Herzegovina arises from the Law on the $\mathrm{CBBH}$. Thus, this institution plays a significant role in development and implementation of policy stability. The greatest part of Bosnia and Herzegovina financial sector represents banking sector. Thus, problems in financial stability in this part of financial sector could cause problems in financial stability of the entire financial sector.

Analyzing the banking sector of Bosnia and Herzegovina from its beginning to today, it can be concluded that it has been significantly changed. First of all, there has been a rise in importance of banks at entire financial system. Also, significant credit growth is noticeable. Furthermore, it is obvious that demand for credits is extremely fast growing. Capital adequacy is, mainly, at satisfactory level. Despite all advantages and positive data from Bosnia and Herzegovina banking sector, it is important to mention that non-performing loans represent the greatest threat to banking health and financial stability, even though they are measuring decreasing trend. Thus, level of non-performing loans at the end of 2018th was around 9\%, which was, mainly, caused by high level of non-performing loans in several banks.

Non-performing loans are one of the greatest obstacles to economic development since their direct impact on credit growth. This led to decrease in credit activity what 
makes this problem solution a priority. They have achieved the highest level in countries that have experienced a deep economic crisis and which even before the crisis has significant credit expansion. Based on all listed above it was appropriate to investigate and examine relation between non-performing loans and financial stability in Bosnia and Herzegovina banking sector. Given results have shown the importance of non-performing loans monitor as well as its effects on banking sector financial stability. Following sections of paper presents related literature, methods, that were used, results as well as concluding remarks.

\section{Literature review}

By analyzing the available literature and other authors' papers, better insight into research situation in this area was gotten. It was researched what the authors of similar intentions are written in the area of credit risk, non-performing loans, financial stability and banking in general. Further, the impact of bank ownership concentration on two riskiness indicators: non-performing loans and capital adequacy were measured. It was proven that concentrated ownership significantly reduces the non-performing loans and that this depends on supervisory control and the right to protection of shareholders. Berle-Means model was tested in order to check if the higher ownership concentration means better performances. Results indicate that banks with greater credit portfolio have better capital adequacy ratios. Also, it was disclosed that banks with poorer managerial efficiency have poorer capital adequacy ratios. Therefore, it was proven that ownership concentration does not have impact on capital adequacy ratio, but it does have a negative impact on non-performing loans. Also, it was proven that stronger supervisory control reduces the impact of ownership concentration on non-performing loans (Shehzad, Haan, \& Scholthes, 2010). Further, the research conducted in Croatia for the subject had level of non-performing loans, level of individual and portfolio risk of Croatia banking sector. The correlations between these variables with macroeconomic indicators were investigated (Šverko, et al., 2010). The connection between credit growth, asset quality and internal and external factors in developing countries was investigated. Authors have proved that economic growth slowdown, the weakening of the exchange rate and fast credit growth are independently connected with higher non-performing loans ratio. (De Bock \& Demyanets, 2012). Next research has proved significant negative impact of import and industrial production on non-performing loans. This means that increase in export and industrial production causes economy increase and follow by that decrease of non-performing loans (Fawad \& Taqadus, 2013). The following research focused only on the financial system in general and its correlation with global imbalances. It was shown that the global imbalance has only a weak correlation with the 
financial imbalance, in comparison with the indicators obtained from the financial system (Taylor, 2013). The effect of pro-cyclicality in the euro area together with impact of Basel III on cyclicality and their reflection on non-performing loans was investigated (Horvatova, 2013).

Financial stability in 14 Asian countries from 2003 to 2010 and the impact of banking competition, concentration, control and state institutions on the likelihood of banks bankruptcy were analyzed. Results have confirmed that greater concentration encourages financial fragility, so that the lower prices cause greater banks exposure (Xiaoqing, Yongija, \& Molyneux, 2014). The following paper investigated the importance of conducting stress tests to support the monitoring of financial stability and the interconnections in the financial system. This research has indicated those short-term and long-term goals of the stress tests to which attention should be paid (Bookstaber, et al., 2014). The following research analyzes the strengths of Central Eastern Europe banking market and impact of financial crisis. The paper presents three conclusions as follows: there is an obvious convergence of the country's development and market power in the pre-crisis period, asset quality and capitalization have direct impact on margin in pre-crisis as well in crisis period (Efthyvoulou \& Yildirim, 2014). Further, research conducted in banking sector of Turkey examines the effects of macroeconomic variables such as commercial loan interest rates and public debt to GDP ratio, on non-performing loans for period 2002-2013. Econometric analysis has shown that changes in non-performing loans could be explained by analyzed macroeconomic variables (Islamoglu, 2015). The authors of the following paper have shown the developement of an aggregate index for financial stability measurement at the Balkans. Actually, this index collapse selected International Monetary Fund Financial Soundness Indicators and macro prudential indicators together with World Balkan developement indicators and measures of world economic climate (Karanovic \& Karanovic, 2015). The following research analyzes Bosnia and Herzegovina banking sector. It focuses on identification of causes and consequences of non-performing loans. Research proves that beter liquidity control leads to lower level of non-performing loans as well as that higher level of non-performing loans leads to lower profitability. This could potentially threaten the bank's capital (Kozarić \& Žunić, 2015). Furthermore, authors have showen that in Baltic countries, real economy responds to non-performing loans and that there is a strong feedback effects from variables such as domestic credit to private sector, GDP growth, unemployment and inflation to non-performing loans (Kjosevski \& Petkovski, 2016). On the other hand, authors have investigated relation between financial development and NPLs. It was proven that financial development, measured by foreign bank presence and financial intermediation, is positively associated with non-performing loans. (Ozili, 2019) Major part of above presented papers analyzes the effects of macroeconomic 
or bank-specific variables on non-performing loans. Others focus mainly on effects of non-performing loans on economy. This paper distincts from previous researches, by focusing on effects of non-performing loans on banking sector financial stability.

\section{Theoretical framework and practical implications}

There are different definitions of non-performing loans. In the narrow sense of the term called, non-performing means those loans that do not earn revenue and of which it is not expected a full refund of principal and interest in the future, as well as loans that delay in interest and principal 90 or more days. International Monetary Fund defines non-performing loans as follows:

- Borrower delay with principal or interest repayment 90 days or more;

- Interest for delay longer than 90 days is refinanced, capitalized or its payment was postponed.

Changes in economic activity have led to weakening of bank asset quality during global financial crisis. Financial stability does not have general accepted definition. Different authors and institutions define it in different ways. Thus, for example, Bundesbank defines financial stability as conditions that enables financial system to fulfils its key functions and that can fulfil them even in situations occurrence of shocks, stresses and structural disorder. In order to ensure and maintain financial stability it is necessary to create adequate system for maintenance which could be represented as follows.

Figure 1: Pyramid of financial stability

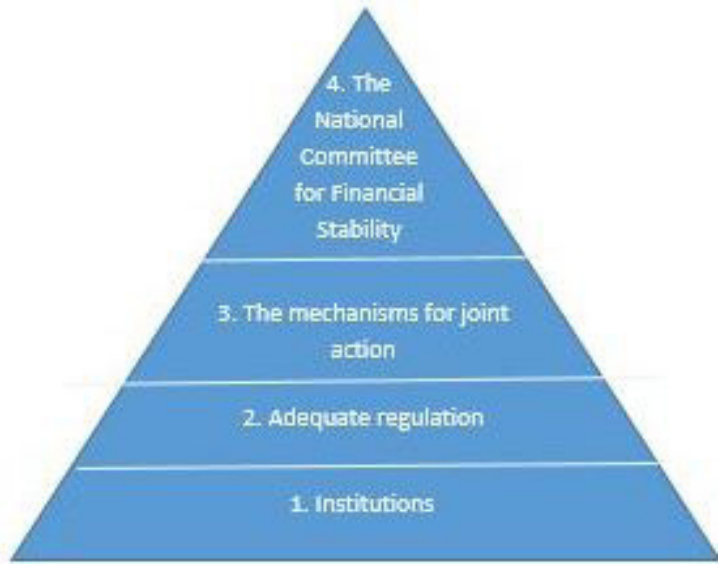

Source: Kozarić, K., \& Fabris, N. (2012). Monetarno - kreditna politika, Štamparija 
Some central banks are still in doubt whether to accept financial stability as their goal since those institutions could not cover all aspects of financial stability. However, it could be predicted that central banks in upcoming years will accept financial stability as its goal and that will be explicitly or implicitly determined. In most countries financial stability maintenance is not just responsibility of central bank, but it is divided between central bank, ministry of finance and supervisor authorities. Central bank of Bosnia and Herzegovina ${ }^{3}$ defines financial stability as conditions that enable financial system to absorb shocks without significant disorder in current and future functioning and that will not negatively affect entire economy. This task of Central bank of Bosnia and Herzegovina derives from the Law on the CBBH. Thus, this institution plays an important role in development and implementation of policy of stability and sustainable growth through the maintenance of local currency stability and financial and economic stability of the entire country. Central bank of Bosnia and Herzegovina through communication with relevant international and domestic institutions ensures process of systematic risk and financial stability tracking. Additional contribution to financial stability maintenance this institution provides through its membership in Standing Committee for Financial Stability.

Bosnia and Herzegovina banking sector has significantly changed since its beginnings to today. It is necessary to emphasize mining of banks in entire economic system. Actually, ratio banking sector asset to BDP is growing . Until beginning of crisis, even during the crisis, credit growth is present. Also, demand for loans have extremely fast growth. The banking sector and its assets are well managed and the level of bad assets is kept at a low level until the advent of the financial crisis. However, crisis advent caused more rigorous credit policy, further highlighting the importance of adequate credit risk management. Current banks capital adequacy is, mainly, at satisfactory level and it is far above those required by the Basel Principles. Non-performing loans are still the greatest threat to health of banking system and its financial stability. Share of non-performing loans in total loans of Bosnia and Herzegovina banking sector at the end of 2018th was around 9\%. Therefore, this type of loans is main source of systematic risk, together with a fact that there is not an adequate solution to this problem. According to Central bank of Bosnia and Herzegovina data, risks from the region are primarily related to the repayment of parent banks to their subsidiaries in Bosnia and Herzegovina. This process is influenced by the capital position strengthen in the euro area banks, what was caused by European Central Bank stress testing that was obtained in all European banking groups. Starting application of new European regulatory framework could potentially affect strengthening effects of the deleveraging process in the upcoming years. Namely, new regulation implies application of international standards of capital and liquidity risk management. Be- 
sides, further development of the banking system determinant is the commitment of foreign banking groups to lend to the economy and inhabitants, wherein it is essential to develop system of non-performing loans problem solving. Namely, all other risks to banking sector financial stability mainly result from credit risk.

\section{Research methodology}

Examination of impulse response function between banking sector financial stability and non-performing loans for Bosnia and Herzegovina banking sector is subject of this paper. For that purposes data on non-performing loans and financial stability for period 2000-2017 were used. Selected period is representative since it covers period before, during and after crisis. These data are obtained from International Monetary Fund Financial Soundness Indicators. Before running the vector autoregression analysis, the determination of appropriate lags length through the Akaike Information Criterion, Schwarz's Bayesian Information Criterion and Hannan and Quinn Information Criterion was carried out. After optimal lag length determination vector autoregression analysis was employed in order to explore how the Bosnia and Herzegovina banking sector financial stability responds to the impulse of changes in non-performing loans. For that purposes the following vector autoregression models were defined.

$$
\begin{aligned}
F S_{t} & =\lambda_{0}+\sum_{i=1}^{n} \lambda_{i} \Delta N P L_{t-1}+\sum_{i=1}^{n} \varphi_{i} F S_{t-i}+\varepsilon_{t} \\
\Delta N P L_{t} & =\lambda_{0}+\sum_{i=1}^{n} \lambda_{i} \Delta N P L_{t-1}+\sum_{i=1}^{n} \varphi_{i} F S_{t-i}+\varepsilon_{t}
\end{aligned}
$$

Wherein the:

- $F S_{t}$ denotes banking sector financial stability in time t;

- $\triangle N P L_{t}$ denotes change in non-performing loans ratio in Bosnia and Herzegovina banking sector;

- $\triangle N P L_{t-1}$ denotes change in non-performing loans ratio in Bosnia and Herzegovina banking sector by taking first difference.

The Granger causality Wald test was performed in order to determine if the changes in non-performing loans Granger-cause financial stability in Bosnia and Herzegovina banking sector. Namely, it was investigated if banking sector financial stability and non-performing loans move together until finding a stable long-term equilibrium following the so-called Granger model. Thus, these assumptions are tested on data from Bosnia and Herzegovina banking sector by the Granger causality model on following way (Engle \& Clive Granger, 1987). 


$$
Y_{t}=\beta_{0}+\sum_{j=1}^{J} \beta_{j} Y_{t-j}+\sum_{k=1}^{K} \tau_{k} X_{t-k}+u_{t}
$$

Wherein denotes banking sector financial stability, denotes non-performing loans in period t-k and denotes error term. Furthermore, $\mathrm{F}$ test will be used to examine the null hypothesis and test whether these two variables move together. Critical problem was choice of lags $\mathrm{J}$ and $\mathrm{K}$ what was solved by application of above-mentioned criteria for optimal lag length selection. This approach enables determination of the causal direction of the relationships, so the revers model can be examined. Namely, $\mathrm{X}$ Granger causes $\mathrm{Y}$ if $\mathrm{Y}$ can be better predicted using historical values of $\mathrm{X}$ and $\mathrm{Y}$ than using only historical values of Y. After that Ordinary Least Squares model was used in order to determine if the changes in non-performing loans could predict Bosnia and Herzegovina banking sector financial stability. At the end in Ordinary Least Squares model selected macroeconomic variables (unemployment rate and growth rate) was included in order to potentially increase predictive power of model.

\section{Results}

First step in analysis was determination of optimal lag length that will be included in the model. According to all criteria's (Schwarz's Bayesian information criterion, Akaike's information criterion and Hannan and Quinn information criterion) two lags should be included in the model. After that, vector autoregression was applied. As it can be seen in the following table, Bosnia and Herzegovina banking sector financial stability negatively reacts to changes in non-performing loans and this response is statistically significant.

Table 1: Vector autoregression results

\begin{tabular}{|c|r|r|r|}
\hline & Coefficient & \multicolumn{1}{|c|}{ T } & \multicolumn{1}{c|}{ P* $^{*}$} \\
\hline FS - lag 1 & -0.1402 & -2.4106 & 0.0384 \\
\hline FS - lag 2 & -0.1189 & -1.1455 & 0.0318 \\
\hline NPL - lag 1 & 0.0053 & 0.1349 & 0.0394 \\
\hline NPL - lag 2 & 0.0025 & 0.1554 & 0.0159 \\
\hline
\end{tabular}

* statistical confindence at $95 \%$

\section{Source: Author's calculations}

Impulse response function refers to the reaction of observed variables on assumed external shocks. Since VAR model includes two variables, this impulse response function also observes reactions of these two variables. The following figure displays those functions. 
Figure 2: The impulse response function of banking sector financial stability and non-performing loans

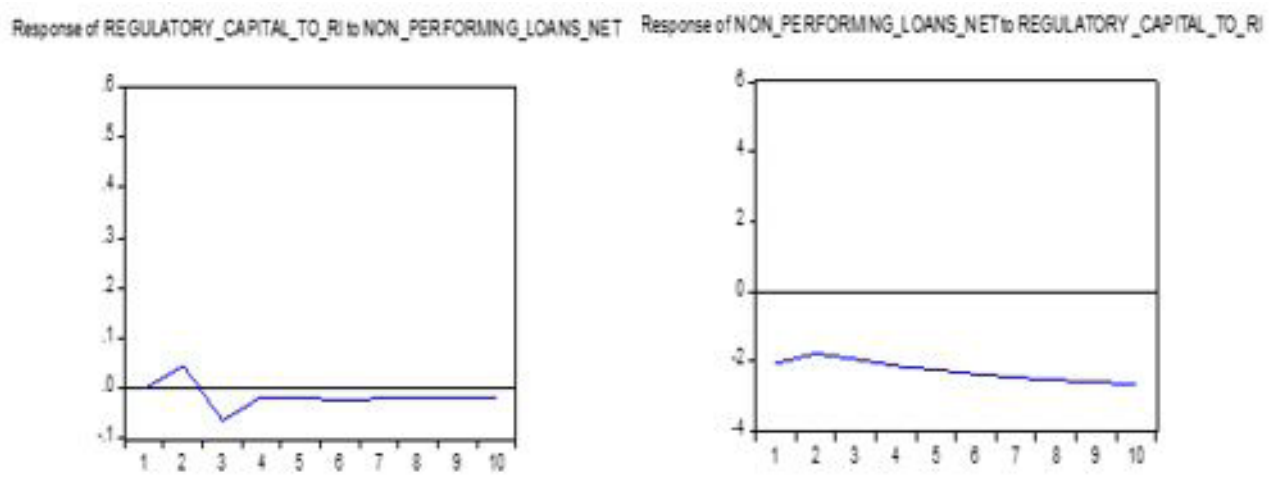

Source: Author's calculations

At the figure 2, the left is the impulse response of banking sector financial stability on changes in non-performing loans. As it can be seen on above figure when the impulse is non-performing loans response of financial stability is positive only in first two periods and then becomes negative. This result was expected since it takes time for financial stability to react on deterioration of banks credit portfolios. At the right site of figure is the impulse response of non-performing loans on changes in financial stability. Negative impact is noticeable, especially as time passes. This result is logical since stricter regulatory polices forces banks to ensure better quality of their credit portfolios.

Granger causality test represent a technique that determine whether one time series is useful in forecasting another. Namely, by application of this test it is possible to determine whether there is a causality relationship between observed variables. Results of Granger causality Wald test demonstrated that non-performing loans cause banking sector financial stability in Bosnia and Herzegovina.

Table 2: Granger causality Wald test results

\begin{tabular}{|c|c|c|r|r|}
\hline $\begin{array}{c}\text { Dependent } \\
\text { variable }\end{array}$ & $\begin{array}{c}\text { Inde- } \\
\text { pendent } \\
\text { variable }\end{array}$ & $\chi^{\mathbf{2}}$ & Df & $\mathbf{P}^{*}$ \\
\hline FS & NPL & 41.753 & 2 & 0.000 \\
\hline
\end{tabular}

* statistical confidence at 95\%

Source: Author's calculations

However, from above presented Granger causality results it can be concluded that when the cause variable is non-performing loans, the $p$ value of this test is 0.000 what is less than critical value 0.05 . Thus, null hypothesis can be rejected. This means that 
banking sector financial stability have Granger causation with non-performing loans. As addition to above analysis and in order to present eventually changes in impact of non-performing loans on financial stability, we have conducted OLS for above model expanded with two new variables: unemployment (Urt) and growth rate (Grt).

Table 3: Ordinary Least Square regression results

\begin{tabular}{|c|r|r|r|}
\hline & Coefficient & T & \multicolumn{1}{c|}{ P* $^{*}$} \\
\hline Constant & 6.5016 & 1.8692 & 0.0705 \\
\hline DNPLt & -0.0635 & -3.3219 & 0.0021 \\
\hline Urt & -0.0420 & -2.3852 & 0.0224 \\
\hline Grt & 1.1438 & 0.9899 & 0.3294 \\
\hline R2 & 0.7880 & & \\
\hline Adjusted R2 & 0.7543 & & \\
\hline
\end{tabular}

* statistical confindence at $95 \%$

Source: Author's calculations

As we can see from above table effects of all macroeconomic variables on banking sector financial stability is statistically significant. In this regard, unemployment rate has a negative and statistically significant impact on banking sector financial stability. On the other hand, regression results have shown that growth rate does not have statistically significant impact on banking sector financial stability. Therefore, it is statistically and practically justified to include unemployment rate in analysis of banking sector financial stability. One of main limitations of this analysis and that could be improved in following researches is measuring of financial stability. Namely, we have decided for one measure and it can be expanded with other indicators. Also, there is a room for future research of other variables to be included in model in order to, potentially, improve its power.

\section{CONCLUSION}

Long and short run connection between non-performing loans and banking sector financial stability is of the greatest importance since it indicates important aspects that could lead to problems not only in banking, but also in entire financial sector. Thus, efficient credit risk management is extremely important for each bank in order to prevail non-performing loans occurrence. On this way, banks are protecting their assets, reserves and capital. This is extremely important since a huge number of non-performing loans write-offs lead to reduction in reserves and capital that could cause technical insolvency of the bank. Banks with high non-performing loans ratio are weak and potentially could fall into liquidity problems. If we look at the problem from the perspective of banking sector, presence of a several banks with same problem potentially could lead to banking sector financial stability deterioration. 
All this led to conclusion that non-performing loans are main source of systematic risk and that, as such, may threaten the financial stability of the entire banking sector. Therefore, this causation should be under the continuous supervision by the regulatory authorities which are responsible for the financial stability maintenance. Namely, above demonstrated long run connection between non-performing loans and banking sector financial stability is of a huge importance since it points to important segment that could cause problems in entire financial system since banks are the main part of Bosnia and Herzegovina financial sector. Although there is a new draft of banking law, this study indicates the problem of inadequate regulation regarding problem of non-performing loans. Currently present way of solving the non-performing loans problem is inefficient which includes long judicial processes and aggravated collection of collateral. Thus, it is necessary to create adequate legal institutions for non-performing loans redemption, restructuring and managing. Future research could include other macroeconomic as well as bank-specific variables in order to increase a predictive power of model.

\section{REFERENCES}

1. Bookstaber, R., Cetina, J., Feldberg, G., Flood, M., \& Glasserman, P. (2014). Stress tests to promote financial stability: Assessing progress and looking to the future. Journal of Risk Management in Financial Institutions, 16-25.

2. De Bock, R., \& Demyanets, A. (2012). Bank asset quality in emerging markets: determinants and spillovers. IMF working paper.

3. Efthyvoulou, G., \& Yildirim, C. (2014). Market power in CEE banking sectors and impact of the global financial crisis. Journal of Banking \& Finance, 11-27.

4. Engle, R., \& Clive Granger. (1987). Co-integration and Error Correction: Representation, Estimation, and Testing. Econometrica, 76-251.

5. Fabris, N. (2010). Aktuelna pitanja crnogorske ekonomije. Podgorica: Centralna banka Crne Gore.

6. Fabris, N. (2010). Aktuelna pitanja crnogorske ekonomije. Podgorica: Centralna banka Crne Gore.

7. Fawad, A., \& Taqadus, B. (2013). Explanatory Power of Macroeconomic Varibales as Determinants of Non-performing loans: Evidence from Pakistan. World Applied Science Journal, 243-255.

8. Horvatova, E. (2013). Analysis of the problem of pro-cyclicaty in the eurozone and procyclicality solutions in Basel III. European financial system. 
9. Islamoglu, M. (2015). The Effect of Macroeconomic Variables on Non-performing Loan Ratio of Publicy Traded Banks in Turkey. Wseas transactions on business and economics, 10-20.

10. Karanovic, G., \& Karanovic, B. (2015). Developing An Agregate Index For Measuring Financial Stability In The Balkans. Procedia Economics and Finance, 3-17.

11. Kemal, K., \& Žunić, E. (2015). Causes and consequences of NPLs in Bosnia and Herzegovina banking sector. Journal of Economic and Social Studies, 127144.

12. Kjosevski, J., \& Petkovski, M. (2016). Non-performing loans in Baltic States: determinants and macroeconomic effects. Baltic Journal of Economics, 25-44.

13. Kozarić, K., \& Fabris, N. (2012). Monetarno - kreditna politika. Sarajevo: Štamparija Fojnica. pp 23.

14. Kozarić, K., \& Žunić, E. (2015). Causes and consequences of NPLs in Bosnia and Herzegovina banking sector. Journal of Economic and Social Studies, 127144.

15. Ozili, P. K. (2019). Non-performing loans and financial development: new evidence. Journal of Risk Finance, 59-81.

16. Shehzad, C. T., Haan, J. D., \& Scholthes, B. (2010). The impact of bank ownership concentration on impaired loans and capital adequacy. Journal of Banking and Finance, 26-38.

17. Šverko, I., Prga, I., \& Vrdoljak, T. (2010). Non-performing loans and loans loss provisions: the case of Croatia. Economic developement perspectives of SEE Region in Global Recession Context, (pp. 50-62).

18. Taylor, A. (2013). External imbalances and financial crises. IMF Working paper.

19. Xiaoqing, F., Yongija, L., \& Molyneux, P. (2014). Bank competition and financial stability in Asia Pacific. Journal of Banking \& Finance, 64-77.

20. Yohanee, T. C. (n.d.). School of Management. Retrieved from Shool of Management: http://www.bath.ac.uk/management/research/papers.htm

21. Živko, I., \& Kandžija, T. (2013). Impact of financial crisis on banking sector stability in Republic Croatia. Poslovna izvrsnost.

22. Centralna banka Bosne i Hercegovine, 2018. Izvještaj o finansijskoj stabilnosti, [online]. Dostupno na: www.cbbh.ba [pristup 20.12.2019.] 
Kemal Kozarić

Emina Žunić Dželihodžić

\title{
ANALIZA UZROČNOSTI NEKVALITNIH KREDITA I FINANSIJSKE STABILNOSTI: PRIMJER BOSNE I HERCEGOVINE
}

\begin{abstract}
ABSTRAKT
Posljednja finansijska kriza za rezultat je imala rast nekvalitetnih kredita što je uzrokovalo mnoge probleme $u$ finansijskoj stabilnosti bankarskih sistema širom svijeta. Ovaj rad analizira implusni odgovor finansijske stabilnosti bankarskog sektora na promjene u nekvalitetnim kreditima u bankarskom sektoru Bosne i Hercegovine. Vektor autoregresiona analiza je korištena kako bi se istražilo kako finansijska stabilnost bankarskog sektora odgovara na implus - promjene nekvalitetnih kredita. Za potrebe analize korišteni su podaci o finansijskoj stabilnosti i nekvalitetnim kreditima za period 2000-2017. godina. Osnovni cilj ovog istraživanja jeste analiza promjene finansijske stabilnosti na osnovu promjene nekvalitetnih kredita. Stoga se svrha ovog rada ogleda u modeliranju povezanosti nekvalitetnih kredita i finansijske stabilnosti. Rezultati istraživanja pokazuju da finansijska stabilnost bankarskog sektora Bosne i Hercegovine negativno reaguje na promjene u nekvalitetnim kreditima. Nadalje, regresioni model je pokazao da rast nekvalitetnih kredita vodi slabljenju finansijske stabilnosti bankarskog sektora. Rezultati, također, upućuju na postojanje kako dugoročne, tako i kratkoročne uzrokovanosti finansijske stabilnosti nekvalitetnim kreditima. Stoga je moguće zaključiti da su nekvalitetni krediti jedan od glavnih izvora sistemskog rizika po finansijsku stabilnost bankarskog sektora, te kao takvi trebaju posebno biti praćeni.
\end{abstract}

